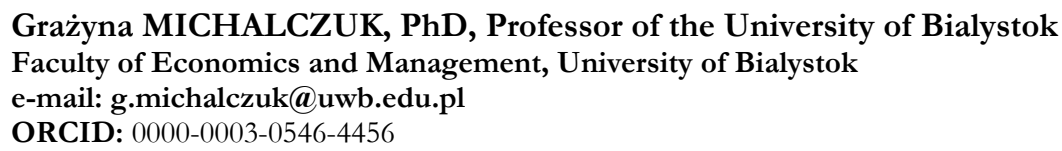

Urszula KONARZEWSKA, MA

Faculty of Economics and Management, University of Bialystok

e-mail: u.konarzewska@uwb.edu.pl

ORCID: 0000-0003-1257-3749

DOI: 10.15290/oes.2018.04.94.07

\title{
THE USE OF GRI STANDARDS IN REPORTING ON ACTIONS BEING TAKEN BY COMPANIES FOR SUSTAINABLE DEVELOPMENT
}

\author{
Summary
}

Objective - to show the specificity and scope of reporting on sustainable development using the GRI Standards. This is currently a significant issue because of the transparency which becomes an important paradigm for conducting business. This means that company's stakeholders are interested not only in the undertaken or declared actions for sustainable development, but also in the access to reliable and comparable information related thereto. In this perspective, GRI Standards play a significant role.

Research methodology - the classical methods of research are used in this paper, such as: the study of the subject-related literature and the analysis of the content of non-financial reports published by selected Polish and foreign companies, which have been prepared in accordance with the GRI Standards.

Result - the carried out studies have pointed at the diversified level of disclosures in the field of sustainable development, which is visible when comparisons are made between countries and within each country. They also allow one to notice the low level of the use of the GRI indicators related to Sustainable Development Goals in the reports prepared by Polish companies covered by the survey.

Originality/value - the paper has cognitive value with regards to the scope and the quality of disclosures concerning actions being taken by companies in the field of sustainable development as well as the role that GRI Standards can play in this process.

Key words: sustainable development, reporting, GRI Standards

JEL classification: M14, Q01, Q56

\section{Introduction}

The demand for information in various substantial and time perspectives constitutes a challenge for reporting. The effect is the constant evolution in terms of reporting the company's actions the aim of which is to beyond the financial aspect from the information policy. It takes place within the non-financial reporting which consists on measuring, disclosing and taking responsibility towards internal and 
external stakeholders for results and efficienty in economic, social and environmental terms [Global Reporting Initiative, 2011, p. 3].

Non-financial reporting is a complex and multi-faceted process. Sustainable development is an essential area of companies' actions which ought to be included in reports. Regulatory institutions notice such necessity, which is visible in the solutions introduced in particular countries. They oblige the selected groups of companies to reveal information concerning social and environmental issues (also in the area of sustainable development).

As the consequence, presently more and more companies are not focused solely on providing information about financial issues. It takes place mainly within the frameworks of separate non-financial reporting. However, what is crucial is that information obtained from it ought to be of proper quality and can be used for making comparisons. It determines the activities that aim at the elaboration and strengthening of stable and widely accepted bases of the information system of companies [Śnieżek, Wiatr, 2014, p. 407] which is based on standards. In the presented perspective the GRI Standards are crucial. Their basic aim is to provide transparent and consistent principles in terms of creating reports on sustainable development and to encourage organizations to present reliable data. It is worth emphasizing that the reports elaborated in accordance with the GRI Standards are not solely the collection of the results of the activities. They also include the adopted strategy and conditionings as well as the aims of sustainable development.

The aim of the paper is to show the specificity and scope of reporting on sustainable development using the GRI Standards. The realization of this aim was possible on the basis of the literature review and the analysis of the contents of nonfinancial reports of selected Polish and foreign companies.

\section{Reporting in the sphere of sustainable development}

Providing stakeholders with transparent, consistent and clear information presenting the achievements of organizations both with regards to the financial and non-financial aspects of conducted activity determines the necessity to go beyond the frameworks of financial reporting [Michalczuk et al., 2017, p. 33]. However, it constitutes a challenge because so far financial reports which are based on standards constituted the main source of information. The reports go beyond financial information in the following ways:

1. Management commentary as a separate part (non-financial information statement).

2. Separate reporting (non-financial reports).

Of particular importance is the development of separate reporting that includes non-financial information. Such reporting is connected with revealing data concerning the company's actions dedicated for separate groups of stakeholders in the precisely defined time perspective [Wróbel, 2016, p. 85]. It means that by means of such reports companies display their economic, social and environmental impact on 
the surrounding and the effects connected with it. The information constitutes the reflection of the companies' actions for sustainable development that is dictated by climate changes, the depletion of the natural resources and by the progressive degradation of the natural environment.

The concept of sustainable development in quality terms constitutes the proposal of a new form of conscious and responsible life having both individual and social character and based on the principle of development together with the social and natural surrounding - while taking into consideration ecological limitations and social expectations. It is based on the assumption that the main objective of actions ought not to be the maximizing of benefits, but the aspiration to create and preserve the socio-economic stability. In this aspect it appears to be crucial to use limited resources in the way that creates conditions for both the development and preservation of high standards in economic, socio-cultural and environmental terms for both particular social groups of the contemporary world and for the future generations [Rogall, 2010, p. 44].

The response to the challenges of sustainable development is the UN Agenda 2030 adopted in 2015 by the UN member states. It comprises 17 Sustainable Development Goals (SDGs) and 169 interrelated tasks which are, to a large degree, based on the Millenium Development Goals (MDGs) realized in the years 2000-2015. Sustainable Development Goals are intended to solve sensitive global problems chiefly by means of adjusting the macroeconomic concept of sustainable development to the economic reality that is targeted at the development of companies [Gadomska-Lila, Wasilewicz, 2016, p. 303].

From the microeconomic perspective (of a company) sustainable development means such strategy of acting that not only satisfies the current needs of the organization and its stakeholders, but also protects, sustains and reinforces man and the sources of resources that will be necessary in the future [Business Strategy..., 1992, p. 1]. Hence of key importance is the involvement of companies in the realization of the concept of sustainable development because only such approach enables all the undertaken actions to constitute a coordinated and logical sequence, which in a long-term perspective will contribute to the realization of the mutual vision of development [astrzębska, 2016, p. 40]. It is dictated by the fact that companies have considerable impact on the rate and quality of the global economic development, shape the level and conditions of employment, decide upon the value and directions of allocating funds for innovations, including the breakthrough social and ecological solutions.

Therefore, transparency becomes an important paradigm of running a business. The company's surrounding is interested not only in the undertaken or declared activities for the realization of Sustainable Development Goals, but chiefly in the effects of such actions. It determines the need to submit specific data connected with it [Global Reporting Initiative ..., 2017, p. 10; Kaputa, 2013, p. 115].

Companies may publish information on the sphere of sustainable development in various documents, among others in the report of the management board or in non-financial (social and integrated) reports. Non-financial reports are not included 
in the standard, owing to which they are characterized by the freedom in the preparation process as well as by varied information scope. They are not subject to the external verification. Owing to this their reliability and comparability are reduced. Therefore, there are undertaken actions that aim at standardizing them. In this aspect particular importance is attached to the instruments elaborated by the Global Reporting Initiative (GRI), the independent international organization established in 1997. The regulations provided by GRI are a certain type of recommendations for the companies making reports that enable them understanding not only the requirements and principles included there, but also the entire process of social reporting [Anam, 2013, p. 71].

The activities of the Global Reporting Initiative include not only preparing the most accepted guidelines regarding reporting, but they also comprise active activities that are undertaken in order to support companies in achieving and submitting reports on the Sustanaible Development Goals. The main assumption of the report prepared in accordance with GRI is the provision of properly balanced information on the organization's effectiveness with regards to sustainable development, both in the positive and negative aspect [Global Reporting Initiative, 2016, p. 3].

A considerable role in reporting sustanaible development is attached to the document referred to as SDG Compass which is elaborated by GRI in cooperation with the UN Global Compact and the World Business Council for Sustainable Development. It ensures, among others, the sets of applicable indicators that specify the contribution in the realization of Sustainable Development Goals. They are included in the latest standards of non-financial reporting prepared by the Global Reporting Initiative - GRI Standards, which consititute the updating of the GRI G4 Guidelines (table 1).

TABLE 1

Indicators included in GRI Standards in combination with Sustainable Development Goals

\begin{tabular}{|c|c|l|}
\hline $\begin{array}{c}\text { Sustainable } \\
\text { Development } \\
\text { Goals }\end{array}$ & \multicolumn{2}{|c|}{ GRI indicators } \\
\hline \multirow{4}{*}{$\begin{array}{c}\text { No poverty } \\
\text { Non }\end{array}$} & $\mathbf{1 0 3 - 2}$ & The management approach and its components \\
\cline { 2 - 3 } & $\mathbf{2 0 2 - 1}$ & $\begin{array}{l}\text { Ratios of standard entry level wage by gender compared to local minimum } \\
\text { wage }\end{array}$ \\
\cline { 2 - 3 } & $\mathbf{2 1 3 - 2}$ & $\begin{array}{l}\text { Significant indirect economic impacts } \\
\text { communities }\end{array}$ \\
\hline \multirow{4}{*}{$\begin{array}{c}2 . \\
\text { Zero hunger }\end{array}$} & $\mathbf{2 0 1 - 1}$ & Direct economic value generated and distributed \\
\cline { 2 - 3 } & $\mathbf{2 0 3 - 1}$ & Infrastructure investments and services supported \\
\cline { 2 - 3 } & $\mathbf{2 0 3 - 2}$ & Significant idirect economic impacts \\
\cline { 2 - 3 } & $\mathbf{4 1 1 - 1}$ & Indicents of violations involving rights of indigenous peoples \\
\cline { 2 - 3 } & $\mathbf{4 1 3 - 2}$ & $\begin{array}{l}\text { Operations with significant actual and potential negative impacts on local } \\
\text { communities }\end{array}$ \\
\hline
\end{tabular}




\begin{tabular}{|c|c|c|}
\hline $\begin{array}{l}\text { Sustainable } \\
\text { Development }\end{array}$ & & GRI indicators \\
\hline \multirow{12}{*}{$\begin{array}{c}3 . \\
\text { Good health } \\
\text { and } \\
\text { well-being }\end{array}$} & $203-2$ & Significant indirect economic impacts \\
\hline & 305-1 & Direct (Scope 1) GHG emissions \\
\hline & $305-2$ & Energy indirect (Scope 2) GHG emissions \\
\hline & $305-3$ & Other indirect (Scope 3) GHG emissions \\
\hline & $305-6$ & Emissions of ozone depleting substances (ODS) \\
\hline & $305-7$ & $\begin{array}{l}\text { Nitrogen oxides }\left(\mathrm{NO}_{\mathrm{X}}\right) \text {, sulphur oxides }\left(\mathrm{SO}_{\mathrm{X}}\right) \text { and other insignificant air } \\
\text { emissions }\end{array}$ \\
\hline & $306-1$ & Water discharge by quality and destination \\
\hline & $306-2$ & Waste by type and disposal method \\
\hline & $306-3$ & Significant spills \\
\hline & $306-4$ & Transport of hazardous waste \\
\hline & $403-2$ & $\begin{array}{l}\text { Types of injury and rates of injury, occupational diseases, lost days and ab- } \\
\text { senteeism and number of work-related fatalities }\end{array}$ \\
\hline & $403-3$ & $\begin{array}{l}\text { Workers with high incidence or high risk of diseases related to their occu- } \\
\text { pation }\end{array}$ \\
\hline \multirow{2}{*}{$\begin{array}{c}4 . \\
\text { Quality } \\
\text { education }\end{array}$} & $102-27$ & Collective knowledge of the highest governance body \\
\hline & $404-1$ & Average hours of training per year, per employee \\
\hline \multirow{15}{*}{$\begin{array}{c}5 . \\
\text { Gender } \\
\text { equality }\end{array}$} & $102-22$ & Composition of the highest governance body and its committees \\
\hline & $102-24$ & Nominating and selecting the highest governance body \\
\hline & $103-2$ & The management approach and its components \\
\hline & 201-1 & Direct economic value generated and distributed \\
\hline & $202-1$ & $\begin{array}{l}\text { Ratios of standard entry level wage by gender compared to local minimum } \\
\text { wage }\end{array}$ \\
\hline & 203-1 & Infrastructure investments and services supported \\
\hline & $401-1$ & New employee hires and employee turnover \\
\hline & $401-3$ & Parental leave \\
\hline & $404-1$ & Average hours of training per year, per employee \\
\hline & 404-3 & $\begin{array}{l}\text { Percentage of employees receiving regular performance and career } \\
\text { development reviews }\end{array}$ \\
\hline & $405-1$ & Diversity of governance bodies and employees \\
\hline & $405-2$ & Ratio of basic salary and remuneration of women to men \\
\hline & $406-1$ & Incidents of discrimination and corrective actions taken \\
\hline & $414-1$ & New suppliers that were screened using social criteria \\
\hline & $414-2$ & Negative social impacts in the supply chain and actions taken \\
\hline \multirow{11}{*}{$\begin{array}{c}6 . \\
\text { Clean } \\
\text { water and } \\
\text { sanitation }\end{array}$} & $303-1$ & Water withdrawal by source \\
\hline & $303-2$ & Water sources significantly affected by withdrawal of water \\
\hline & 303-3 & Water recycled and reused \\
\hline & $304-1$ & $\begin{array}{l}\text { Operational sites owned, leased, managed in, or adjacent to, protected } \\
\text { areas and areas of high biodiversity value outside protected areas }\end{array}$ \\
\hline & 304-2 & Significant impacts of activities, products and services on biodiversity \\
\hline & 304-3 & Habitats protected or restored \\
\hline & $304-4$ & $\begin{array}{l}\text { IUCN Red List species and national conservation list species with habitats } \\
\text { in areas affected by operations }\end{array}$ \\
\hline & $306-1$ & Water discharge by quality and destination \\
\hline & $306-2$ & Waste by type and disposal method \\
\hline & $306-3$ & Significant spills \\
\hline & $306-5$ & Water bodies affected by water discharges and/or runoff \\
\hline
\end{tabular}




\begin{tabular}{|c|c|c|}
\hline $\begin{array}{l}\text { Sustainable } \\
\text { development }\end{array}$ & \multicolumn{2}{|r|}{ GRI indicators } \\
\hline \multirow{7}{*}{$\begin{array}{c}7 . \\
\text { Affordable } \\
\text { and clean } \\
\text { energy }\end{array}$} & 201-1 & Direct economic value generated and distributed \\
\hline & 203-1 & Infrastructure investments and services supported \\
\hline & $302-1$ & Energy consumption within the organization \\
\hline & $302-2$ & Energy consumption outside the organization \\
\hline & $302-3$ & Energy intensity \\
\hline & $302-4$ & Reduction of energy consumption \\
\hline & $302-5$ & Reductions in energy requirements of products and services \\
\hline \multirow{34}{*}{$\begin{array}{c}8 . \\
\text { Decent work } \\
\text { and economic } \\
\text { growth }\end{array}$} & $102-41$ & Collective bargaining agreements \\
\hline & $102-8$ & Information on employees and other workers \\
\hline & $103-2$ & The management approach and its components \\
\hline & $201-1$ & Direct economic value generated and distributed \\
\hline & $202-1$ & $\begin{array}{l}\text { Ratios of standard entry level wage by gender compared to local minimum } \\
\text { wage }\end{array}$ \\
\hline & $202-2$ & Proportion of senior management hired from the local community \\
\hline & $203-2$ & Significant indirect economic impacts \\
\hline & $301-1$ & Materials used by weight or volume \\
\hline & $301-2$ & Recycled input materials used \\
\hline & $301-3$ & Reclaimed products and their packaging materials \\
\hline & $302-1$ & Energy consumption within the organization \\
\hline & $302-2$ & Energy consumption outside the organization \\
\hline & $302-3$ & Energy intensity \\
\hline & $302-4$ & Reduction of energy consumption \\
\hline & $302-5$ & Reductions in energy requirements of products and services \\
\hline & 303-3 & Water recycled and reused \\
\hline & $401-1$ & New employee hires and employee turnover \\
\hline & $401-2$ & $\begin{array}{l}\text { Benefits provided to full-time employees that are not provided to tempo- } \\
\text { rary or part-time employees }\end{array}$ \\
\hline & $401-3$ & Parental leave \\
\hline & $402-1$ & Minimum notice periods regarding operational changes \\
\hline & $403-1$ & $\begin{array}{l}\text { Workers representation in formal joint management-worker health and } \\
\text { safety committees }\end{array}$ \\
\hline & $403-2$ & $\begin{array}{l}\text { Types of injury and rates of injury, occupational diseases, lost days and } \\
\text { absenteeism and number of work-related fatalities }\end{array}$ \\
\hline & $403-3$ & $\begin{array}{l}\text { Workers with high incidence or high risk of diseases related to their } \\
\text { occupation }\end{array}$ \\
\hline & $403-4$ & Health and safety topics covered in formal agreements with trade unions \\
\hline & $404-1$ & Average hours of training per year, per employee \\
\hline & $404-2$ & Programs for upgrading employee skills and transition assistance programs \\
\hline & 404-3 & $\begin{array}{l}\text { Percentage of employees receiving regular performance and career } \\
\text { development reviews }\end{array}$ \\
\hline & $405-1$ & Diversity of governance bodies and employees \\
\hline & $405-2$ & Ratio of basic salary and remuneration of women to men \\
\hline & $406-1$ & Incidents of discrimination and corrective actions taken \\
\hline & $407-1$ & $\begin{array}{l}\text { Operations and suppliers in which the right to freedom of association and } \\
\text { collective bargaining may be at risk }\end{array}$ \\
\hline & $408-1$ & Operations and suppliers at significant risk for incidents of child labor \\
\hline & $409-1$ & $\begin{array}{l}\text { Operations and suppliers at significant risk for incidents of forced or com- } \\
\text { pulsory labor }\end{array}$ \\
\hline & 414-1 & New suppliers that were screened using social criteria \\
\hline
\end{tabular}




\begin{tabular}{|c|c|c|}
\hline \multirow{2}{*}{$\begin{array}{c}\text { Sustainable } \\
\text { development } \\
\text { goals }\end{array}$} & \multicolumn{2}{|r|}{ GRI indicators } \\
\hline & $414-2$ & Negative social impacts in the supply chain and actions taken \\
\hline \multirow{2}{*}{$\begin{array}{c}9 . \\
\text { Industry, } \\
\text { innovation } \\
\text { and infra- } \\
\text { structure }\end{array}$} & 201-1 & Direct economic value generated and distributed \\
\hline & 203-1 & Infrastructure investments and services supported \\
\hline \multirow{2}{*}{$\begin{array}{c}10 . \\
\text { Reduced } \\
\text { inequalities }\end{array}$} & $203-2$ & Significant indirect economic impacts \\
\hline & $405-2$ & Ratio of basic salary and remuneration of women to men \\
\hline $\begin{array}{c}11 . \\
\text { Sustainable } \\
\text { cities and } \\
\text { communities }\end{array}$ & 203-1 & Infrastructure investments and services supported \\
\hline \multirow{20}{*}{$\begin{array}{c}12 . \\
\text { Responsible } \\
\text { consumption } \\
\text { and } \\
\text { production }\end{array}$} & 204-1 & Proportion of spending on local suppliers \\
\hline & 301-1 & Materials used by weight or volume \\
\hline & $301-2$ & Recycled input materials used \\
\hline & $301-3$ & Reclaimed products and their packaging materials \\
\hline & $302-1$ & Energy consumption within the organization \\
\hline & $302-2$ & Energy consumption outside the organization \\
\hline & $302-3$ & Energy intensity \\
\hline & $302-4$ & Reduction of energy consumption \\
\hline & $302-5$ & Reductions in energy requirements of products and services \\
\hline & 303-3 & Water recycled and reused \\
\hline & $305-1$ & Direct (Scope 1) GHG emissions \\
\hline & $305-2$ & Energy indirect (Scope 2) GHG emissions \\
\hline & $305-3$ & Other indirect (Scope 3) GHG emissions \\
\hline & $305-6$ & Emissions of ozone depleting substances (ODS) \\
\hline & $305-7$ & $\begin{array}{l}\text { Nitrogen oxides }\left(\mathrm{NO}_{\mathrm{X}}\right) \text {, sulphur oxides }\left(\mathrm{SO}_{\mathrm{X}}\right) \text { and other insignificant air } \\
\text { emissions }\end{array}$ \\
\hline & $306-1$ & Water discharge by quality and destination \\
\hline & $306-2$ & Waste by type and disposal method \\
\hline & $306-3$ & Significant spills \\
\hline & $306-4$ & Transport of hazardous waste \\
\hline & 417-1 & Requirements for product and service information and labeling \\
\hline \multirow{13}{*}{$\begin{array}{c}13 . \\
\text { Climate } \\
\text { action }\end{array}$} & $201-2$ & $\begin{array}{l}\text { Financial implications and other risks and opportunities due to climate } \\
\text { change }\end{array}$ \\
\hline & $302-1$ & Energy consumption within the organization \\
\hline & $302-2$ & Energy consumption outside the organization \\
\hline & $302-3$ & Energy intensity \\
\hline & $302-4$ & Reduction of energy consumption \\
\hline & $302-5$ & Reductions in energy requirements of products and services \\
\hline & $305-1$ & Direct (Scope 1) GHG emissions \\
\hline & $305-2$ & Energy indirect (Scope 2) GHG emissions \\
\hline & $305-3$ & Other indirect (Scope 3) GHG emissions \\
\hline & $305-4$ & GHG emissions intensity \\
\hline & $305-5$ & Reduction of GHG emissions \\
\hline & $305-6$ & Emissions of ozone depleting substances (ODS) \\
\hline & $305-7$ & $\begin{array}{l}\text { Nitrogen oxides }\left(\mathrm{NO}_{\mathrm{x}}\right) \text {, sulphur oxides }\left(\mathrm{SO}_{\mathrm{x}}\right) \text { and other insignificant air } \\
\text { emissions }\end{array}$ \\
\hline
\end{tabular}




\begin{tabular}{|c|c|c|}
\hline $\begin{array}{l}\text { Sustainable } \\
\text { development }\end{array}$ & \multicolumn{2}{|r|}{ GRI indicators } \\
\hline \multirow{12}{*}{$\begin{array}{c}14 . \\
\text { Life } \\
\text { below } \\
\text { water }\end{array}$} & $304-1$ & $\begin{array}{l}\text { Operational sites owned, leased, managed in, or adjacent to, protected } \\
\text { areas and areas of high biodiversity value outside protected areas }\end{array}$ \\
\hline & 304-2 & Significant impacts of activities, products and services on biodiversity \\
\hline & $304-3$ & Habitats protected or restored \\
\hline & $304-4$ & $\begin{array}{l}\text { IUCN Red List species and national conservation list species with habitats } \\
\text { in areas affected by operations }\end{array}$ \\
\hline & $305-1$ & Direct (Scope 1) GHG emissions \\
\hline & $305-2$ & Energy indirect (Scope 2) GHG emissions \\
\hline & $305-3$ & Other indirect (Scope 3) GHG emissions \\
\hline & $305-4$ & GHG emissions intensity \\
\hline & $305-5$ & Reduction of GHG emissions \\
\hline & $305-7$ & $\begin{array}{l}\text { Nitrogen oxides }\left(\mathrm{NO}_{\mathrm{x}}\right) \text {, sulphur oxides }\left(\mathrm{SO}_{\mathrm{x}}\right) \text { and other insignificant air } \\
\text { emissions }\end{array}$ \\
\hline & $306-1$ & Water discharge by quality and destination \\
\hline & $306-3$ & Significant spills \\
\hline & $304-1$ & $\begin{array}{l}\text { Operational sites owned, leased, managed in, or adjacent to, protected ar- } \\
\text { eas and areas of high biodiversity value outside protected areas }\end{array}$ \\
\hline & $304-2$ & Significant impacts of activities, products and services on biodiversity \\
\hline & $304-3$ & Habitats protected or restored \\
\hline & $304-4$ & $\begin{array}{l}\text { IUCN Red List species and national conservation list species with habitats } \\
\text { in areas affected by operations }\end{array}$ \\
\hline & $305-1$ & Direct (Scope 1) GHG emissions \\
\hline I. 15 . & $305-2$ & Energy indirect (Scope 2) GHG emissions \\
\hline & $305-3$ & Other indirect (Scope 3) GHG emissions \\
\hline & $305-4$ & GHG emissions intensity \\
\hline & $305-5$ & Reduction of GHG emissions \\
\hline & $305-7$ & $\begin{array}{l}\text { Nitrogen oxides }\left(\mathrm{NO}_{\mathrm{X}}\right) \text {, sulphur oxides }\left(\mathrm{SO}_{\mathrm{X}}\right) \text { and other insignificant air } \\
\text { emissions }\end{array}$ \\
\hline & $306-3$ & Significant spills \\
\hline & $306-5$ & Water bodies affected by water discharges and/or runoff \\
\hline & $102-16$ & Values, principles, standards, and norms of behavior \\
\hline & $102-17$ & Mechanisms for advice and concerns about ethics \\
\hline & $102-21$ & Consulting stakeholders on economic, environmental, and social topics \\
\hline & $102-22$ & Composition of the highest governance body and its committees \\
\hline & $102-23$ & Chair of the highest governance body \\
\hline & $102-24$ & Nominating and selecting the highest governance body \\
\hline & $102-25$ & Conflicts of interest \\
\hline & $102-29$ & Identifying and managing economic, environmental and social impacts \\
\hline 16. & $102-37$ & Stakeholders' involvement in remuneration \\
\hline Peace, justice & $103-2$ & The management approach and its components \\
\hline and strong & $205-1$ & Operations assessed for risks related to corruption \\
\hline & $205-2$ & Communication and training about anti-corruption policies and procedures \\
\hline & 205-3 & Confirmed incidents of corruption and actions taken \\
\hline & 206-1 & $\begin{array}{l}\text { Legal actions for anti-competitive behavior, anti-trust and monopoly } \\
\text { practices }\end{array}$ \\
\hline & $307-1$ & Non-compliance with environmental laws and regulations \\
\hline & $406-1$ & Incidents of discrimination and corrective actions taken \\
\hline & $408-1$ & Operations and suppliers at significant risk for incidents of child labor \\
\hline & $410-1$ & Security personnel trained in human rights policies or procedures \\
\hline
\end{tabular}




\begin{tabular}{|c|c|c|}
\hline $\begin{array}{c}\text { Sustainable } \\
\text { development } \\
\text { goals }\end{array}$ & \multicolumn{2}{|r|}{ GRI indicators } \\
\hline & 414-1 & New suppliers that were screened using social criteria \\
\hline & $414-2$ & Negative social impacts in the supply chain and actions taken \\
\hline & $415-1$ & Political contributions \\
\hline & $416-2$ & $\begin{array}{l}\text { Incidence of non-compliance concerning the health and safety impacts of } \\
\text { products and services }\end{array}$ \\
\hline & $417-1$ & Requirements for product and service information and labeling \\
\hline & $417-2$ & $\begin{array}{l}\text { Incidents of non-compliance concerning product and service information } \\
\text { and labeling }\end{array}$ \\
\hline & $418-1$ & $\begin{array}{l}\text { Substantiated complaints concerning breaches of consumer privacy and } \\
\text { losses of consumer data }\end{array}$ \\
\hline & $419-1$ & Non-compliance with laws and regulations in the social and economic area \\
\hline $\begin{array}{c}17 . \\
\text { Partnerships } \\
\text { for the goals }\end{array}$ & 203-2 & Significant indirect economic impacts \\
\hline
\end{tabular}

Source: own elaboration on the basis of: [SDG Compass. Linking the SDGs and GRI..., pp. 2-41].

The indicators included in the SDG Compass document enable companies not only the selection of the most adequate measures that facilitate informing the stakeholders on the actions taken in order to achieve sustainable development goals. Additionally, they show in what way companies may measure and manage these actions and also place the idea of sustainable development in the centre of the realized business strategies [SDG Compass. The guide for business ..., p. 2].

More importantly, the purpose of SDG Compass is not to burden companies with new reporting frameworks in the area of sustainable development. It is supposed to be a joint platform for analyzing and communicating the interrelated activities while using the previously applied instruments, but in the new way that conforms to the latest Sustainable Development Goals [Global Compact Poland, 2016, p. 45].

\section{The diagnosis of using the GRI Standards with reference to Sustainable Development Goals}

Presently in Poland more than $80 \%$ of non-financial reports are prepared on the basis of the Sustainability Reporting Framework prepared by Global Reporting Initiative (GRI). Most frequently the recommendations in the GRI G4 version are used for that purpose. Additionally, it needs emphasizing that some companies decide to prepare reports on the basis of the latest GRI Standards which on 1 July 2018 replaced the GRI G4 guidelines. In comparison with the previous version they are more comprehensible, have better structure and it is easier to apply them [Sikacz, 2017 , p. 152]. In the most holistic way they present the economic, social and environmental aspects of the activity and provide information on both the positive and negative impact of an organization in the realization of the concept of sustainable development. The entities using GRI Standards are three companies comprised by 
the RESPECT index: The Bank Millennium SA, JSW SA and Inter Cars SA (table 2). ${ }^{1}$

TABLE 2

The presence of indicators referring to the Sustanaible Development Goals

\begin{tabular}{|c|c|c|c|}
\hline $\begin{array}{l}\text { Sustainable } \\
\text { Development } \\
\text { Goals }\end{array}$ & $\begin{array}{l}\text { Millennium Bank } \\
\text { (2017 Financial } \\
\text { and Social Report) }\end{array}$ & $\begin{array}{c}\text { JSW (2017 } \\
\text { Sustainable } \\
\text { Development } \\
\text { Report) }\end{array}$ & $\begin{array}{l}\text { Inter Cars (Report } \\
\text { on non-financial } \\
\text { information } \\
\text { for 2017) }\end{array}$ \\
\hline 1. No poverty & $103-2$ & $103-2 ; 413-2$ & $103-2 ; 202-1$ \\
\hline 2. Zero hunger & $201-1 ; 203-1$ & 413-2; & 201-1; \\
\hline $\begin{array}{l}\text { 3. Good health } \\
\text { and well-being }\end{array}$ & $305-1 ; 306-2 ; 403-2$ & $\begin{array}{l}306-1 ; 306-2 \\
403-2 ; 403-3\end{array}$ & $306-2$ \\
\hline 4. Quality education & $404-1$ & $\times$ & $404-1$ \\
\hline 5. Gender equality & $\begin{array}{l}\text { 103-2; 201-1; 203-1; } \\
401-1 ; 401-3 ; 404-1 ; \\
404-3 ; 405-1 ; 405-2 \\
406-1\end{array}$ & $\begin{array}{l}103-2 ; 401-1 ; \\
401-3\end{array}$ & $\begin{array}{l}\text { 103-2; 201-1; 202-1; } \\
\text { 401-1; 404-1; 404-3; } \\
406-1\end{array}$ \\
\hline $\begin{array}{l}\text { 6. Clean water and } \\
\text { sanitation }\end{array}$ & $303-1 ; 306-2$ & $306-1 ; 306-2$ & $306-2$ \\
\hline $\begin{array}{l}\text { 7. Affordable and } \\
\text { clean energy }\end{array}$ & $\begin{array}{l}201-1 ; 203-1 ; 302-1 ; 302- \\
4\end{array}$ & $302-1$ & $302-1 ; 302-3 ; 302-4$ \\
\hline $\begin{array}{l}\text { 8. Decent work and } \\
\text { economic growth }\end{array}$ & $\begin{array}{l}102-41 ; 102-8 ; 103-2 ; \\
201-1 ; 202-2 ; 203-2 ; 301- \\
1 ; 302-1 ; 302-4 ; 401-1 ; \\
401-2 ; 401-3 ; 403-2 ; 404- \\
1 ; 404-2 ; 404-3 ; 405-1 ; \\
405-2 ; 406-1\end{array}$ & $\begin{array}{l}102-41 ; 102-8 \\
103-2 ; 302-1 ; \\
401-3 ; 402-1 ; \\
403-1 ; 403-2\end{array}$ & $\begin{array}{l}102-41 ; 102-8 ; 103-2 \\
201-1 ; 202-1 ; 202-2 ; \\
302-1 ; 302-3 ; 302-4 ; \\
401-1 ; 404-1 ; 404-3\end{array}$ \\
\hline $\begin{array}{l}\text { 9. Industry, } \\
\text { innovation and } \\
\text { infrastructure }\end{array}$ & $201-1 ; 203-1$ & $x$ & $201-1$ \\
\hline $\begin{array}{l}\text { 10. Reduced } \\
\text { inequalities }\end{array}$ & $405-2$ & $x$ & $\times$ \\
\hline $\begin{array}{l}\text { 11. Sustainable cities } \\
\text { and communities }\end{array}$ & $203-1$ & $\times$ & $\times$ \\
\hline $\begin{array}{l}\text { 12. Responsible } \\
\text { consumption } \\
\text { and production }\end{array}$ & $\begin{array}{l}204-1 ; 301-1 ; 302-1 ; 302- \\
4 ; 305-1 ; 306-2417-1\end{array}$ & $\begin{array}{l}302-1 ; 306-1 \\
306-2 ; 306-3\end{array}$ & $302-1 ; 302-3 ; 302-4$ \\
\hline 13. Climate action & $302-1 ; 302-4 ; 305-1$ & $302-1$ & $302-1 ; 302-3 ; 302-4$ \\
\hline
\end{tabular}

1 The selection of these entities results not only from the fact that in the process of non-financial reporting they use the latest GRI Standards. Another important reason is that the documents prepared by them include information that presents the activity of these companies in 2017. 


\begin{tabular}{|c|c|c|c|}
\hline $\begin{array}{c}\text { Sustainable } \\
\text { Development } \\
\text { Goals }\end{array}$ & $\begin{array}{l}\text { Millennium Bank } \\
\text { (2017 Financial } \\
\text { and Social Report) }\end{array}$ & $\begin{array}{c}\text { JSW (2017 } \\
\text { Sustainable } \\
\text { Development } \\
\text { Report) }\end{array}$ & $\begin{array}{l}\text { Inter Cars (Report } \\
\text { on non-financial } \\
\text { information } \\
\text { for 2017) }\end{array}$ \\
\hline 14. Life below water & $305-1$ & $306-1$ & $\times$ \\
\hline 15. Life on land & $305-1$ & $\times$ & $x$ \\
\hline $\begin{array}{l}\text { 16. Peace, justice } \\
\text { and strong } \\
\text { institutions }\end{array}$ & $\begin{array}{l}102-16 ; 102-17 ; 102-25 ; \\
103-2 ; 205-1 ; 205-2 ; 205- \\
3 ; 206-1 ; 307-1 ; 406-1 ; \\
415-1 ; 417-1 ; 418-1 ; 419- \\
1\end{array}$ & $\begin{array}{l}102-16 ; 103-2 ; \\
205-3 ; 419-1\end{array}$ & $\begin{array}{l}102-16 ; 103-2 ; 205-3 \\
206-1 ; 406-1\end{array}$ \\
\hline $\begin{array}{l}\text { 17. Partnerships } \\
\text { for the goals }\end{array}$ & ( & $x$ & $\times$ \\
\hline
\end{tabular}

Source: own elaboration on the basis of: [Raport finansowy i spoteczny..., 2017; Raport Zrównoważonego Rozwoju, 2017; Sprawozdanie na temat informacii niefinansowych..., 2017].

The analysis of the contents of the reports in fact does not entitle one to make more general conclusions on the level of reporting companies in terms of the realization of Sustainable Development Goals while using the GRI Standards. However, it presents the general tendencies in this aspect.

The analyzed reports were prepared on the basis of the core conformity level of the presented contents with the framework reporting rules specified in the GRI Standards. It does not compel the companies submitting their reports to reveal all the indicators that refer to Sustainable Development Goals. This fact was reflected in the number of GRI indicators reported by particular companies.

The priority reporting areas include: Gender equality, Decent work and economic growth, Responsible consumption and production as well as Peace, justice and strong institutions. The most frequently reported indicators connected with these areas include:

- GRI 102-8: information on employees and other workers,

- GRI 102-16: values, principles, standards, and norms of behavior,

- GRI 102-41: collective bargaining agreements,

- GRI 103-2: the management approach and its components,

- GRI 205-3: confirmed incidents of corruption and actions taken,

- GRI 302-1: energy consumption within the organization,

- $\quad$ GRI 401-1: new employee hires and employee turnover.

In terms of reporting sustainable development companies draw the least attention to such areas as: Partnerships for the goals, Life on land, Sustainable cities and communities, Reduced inequalities and Quality education. The reason of it may be the fact that not all the Goals must have the same importance from the perspective of particular companies. It depends on the specific character of the branch or on the type of the conducted economic activity. Another reason may lie in the fact that these entities have still not elaborated internal procedures enabling the identification, measurement and reporting of the aspects referring to all the Sustainable Development Goals. 
Additionally, the conducted analysis shows the diverse scope of information revealed by particular companies. The report prepared by Millennium Bank lacks indicators that refer solely to one Sustainable Development Goal. In case of reports of JSW and Inter Cars it is difficult to find indicators that would be connected with six and five areas specified in Agenda 2030.

Hence one may assume that the analyzed companies to a low degree use the indicators included in which enable measuring and reporting Sustainable Development Goals. It is visible in comparisons of them with other companies from European countries that prepared their non-financial reports for 2017 on the basis of the GRI Standards (table 3).

TABLE 3

The levels of using GRI indicators connected with Sustainable Development Goals (\%)

\begin{tabular}{|c|c|c|c|c|c|c|c|c|c|c|c|c|c|c|c|c|c|}
\hline \multirow{2}{*}{$\begin{array}{l}\text { Com- } \\
\text { pany }\end{array}$} & \multicolumn{17}{|c|}{ Sustainable Development Goals } \\
\hline & 1 & 2 & 3 & 4 & 5 & 6 & 7 & 8 & 9 & 10 & 11 & 12 & 13 & 14 & 15 & 16 & 17 \\
\hline \multicolumn{18}{|c|}{ Austria } \\
\hline Palfinger & 50 & 40 & 42 & 50 & 60 & 0 & 71 & 66 & 50 & 50 & 0 & 40 & 69 & 33 & 33 & 69 & 100 \\
\hline $\begin{array}{l}\text { AMAG } \\
\text { Metall }\end{array}$ & 25 & 20 & 33 & 50 & 47 & 36 & 43 & 43 & 50 & 0 & 0 & 40 & 39 & 33 & 33 & 23 & 0 \\
\hline \multicolumn{18}{|c|}{ Switzerland } \\
\hline $\begin{array}{l}\text { Partners } \\
\text { Group }\end{array}$ & 0 & 40 & 0 & 50 & 33 & 0 & 29 & 20 & 100 & 0 & 100 & 5 & 0 & 0 & 0 & 12 & 0 \\
\hline $\begin{array}{l}\text { Swiss } \\
\text { Post } \\
\end{array}$ & 75 & 40 & 5 & 50 & 80 & 0 & 86 & 80 & 50 & 50 & 0 & 50 & 100 & 50 & 50 & 50 & 0 \\
\hline \multicolumn{18}{|c|}{ Germany } \\
\hline SAP SE & 50 & 40 & 67 & 50 & 40 & 0 & 86 & 60 & 50 & 100 & 100 & 55 & 92 & 50 & 50 & 35 & 100 \\
\hline $\begin{array}{l}\text { ZEISS } \\
\text { Group }\end{array}$ & 50 & 60 & 33 & 50 & 53 & 18 & 57 & 43 & 100 & 0 & 100 & 20 & 46 & 25 & 25 & 62 & 0 \\
\hline Covestro & 25 & 20 & 58 & 0 & 47 & 27 & 57 & 43 & 50 & 0 & 0 & 50 & 62 & 42 & 42 & 66 & 0 \\
\hline $\begin{array}{l}\text { TAKKT } \\
\text { AG }\end{array}$ & 50 & 80 & 58 & 100 & 80 & 27 & 74 & 100 & 100 & 100 & 100 & 50 & 69 & 58 & 58 & 96 & 0 \\
\hline $\begin{array}{l}\text { BMW } \\
\text { Group }\end{array}$ & 50 & 60 & 67 & 100 & 87 & 0 & 100 & 77 & 100 & 100 & 100 & 65 & 100 & 50 & 50 & 65 & 100 \\
\hline $\begin{array}{l}\text { Wirtscha- } \\
\text { ftsbe- } \\
\text { triebe } \\
\text { Duisburg } \\
\text { - AöR }\end{array}$ & 75 & 60 & 58 & 50 & 67 & 27 & 57 & 63 & 50 & 100 & 100 & 50 & 39 & 25 & 25 & 35 & 100 \\
\hline \multicolumn{18}{|c|}{ Spain } \\
\hline $\begin{array}{l}\text { Enagas } \\
\text { S.A. }\end{array}$ & 75 & 60 & 92 & 100 & 80 & 100 & 86 & 74 & 50 & 50 & 0 & 69 & 100 & 100 & 100 & 77 & 0 \\
\hline $\begin{array}{l}\text { Accen- } \\
\text { ture } \\
\text { Spain } \\
\end{array}$ & 100 & 80 & 100 & 100 & 100 & 100 & 100 & 100 & 100 & 100 & 100 & 95 & 100 & 100 & 100 & 81 & 100 \\
\hline $\begin{array}{l}\text { Esade } \\
\text { Business }\end{array}$ & 25 & 20 & 17 & 50 & 40 & 18 & 43 & 40 & 50 & 0 & 0 & 80 & 15 & 0 & 0 & 12 & 0 \\
\hline \multicolumn{18}{|c|}{ Poland } \\
\hline $\begin{array}{l}\text { Millen- } \\
\text { nium } \\
\text { Bank }\end{array}$ & 25 & 40 & 25 & 50 & 67 & 18 & 57 & 54 & 100 & 50 & 100 & 35 & 23 & 8 & 8 & 54 & 0 \\
\hline JSW & 50 & 20 & 33 & 0 & 20 & 18 & 14 & 23 & 0 & 0 & 0 & 20 & 7 & 8 & 0 & 15 & 0 \\
\hline $\begin{array}{l}\text { Inter } \\
\text { Cars } \\
\end{array}$ & 50 & 20 & 8 & 50 & 47 & 9 & 43 & 34 & 50 & 0 & 0 & 15 & 23 & 0 & 0 & 19 & 0 \\
\hline \multicolumn{18}{|c|}{ Finland } \\
\hline Tokmani & 25 & 20 & 50 & 0 & 53 & 9 & 43 & 49 & 50 & 50 & 0 & 40 & 46 & 42 & 42 & 65 & 0 \\
\hline Sato Oyj & 50 & 60 & 42 & 50 & 53 & 18 & 57 & 37 & 100 & 50 & 0 & 35 & 46 & 33 & 33 & 42 & 0 \\
\hline
\end{tabular}




\begin{tabular}{|l|c|c|c|c|c|c|c|c|c|c|c|c|c|c|c|c|c|}
\hline $\begin{array}{l}\text { Com- } \\
\text { pany }\end{array}$ & $\mathbf{1}$ & $\mathbf{2}$ & $\mathbf{3}$ & $\mathbf{4}$ & $\mathbf{5}$ & $\mathbf{6}$ & $\mathbf{7}$ & $\mathbf{8}$ & $\mathbf{9}$ & $\mathbf{1 0}$ & $\mathbf{1 1}$ & $\mathbf{1 2}$ & $\mathbf{1 3}$ & $\mathbf{1 4}$ & $\mathbf{1 5}$ & $\mathbf{1 6}$ & $\mathbf{1 7}$ \\
\hline & $\mathbf{1 0}$ \\
\hline Citycon & 50 & 20 & 67 & 50 & 60 & 46 & 57 & 49 & 50 & 50 & 0 & 45 & 62 & 50 & 50 & 81 & 0 \\
\hline \multicolumn{10}{|c|}{ Great Britain } \\
\hline $\begin{array}{l}\text { Grainger } \\
\text { PLC }\end{array}$ & 75 & 80 & 42 & 100 & 60 & 0 & 100 & 43 & 100 & 50 & 100 & 40 & 85 & 42 & 42 & 43 & 100 \\
\hline $\begin{array}{l}\text { Conva- } \\
\text { Tec }\end{array}$ & 0 & 20 & 50 & 50 & 47 & 36 & 71 & 46 & 50 & 50 & 0 & 55 & 69 & 33 & 33 & 77 & 0 \\
\hline & \multicolumn{10}{|c|}{ The Netherlands } & & & & \\
\hline DSM & 75 & 80 & 100 & 100 & 93 & 100 & 86 & 86 & 100 & 100 & 100 & 95 & 92 & 100 & 100 & 73 & 100 \\
\hline $\begin{array}{l}\text { ING } \\
\text { Group }\end{array}$ & 25 & 60 & 42 & 50 & 40 & 0 & 100 & 31 & 100 & 100 & 100 & 45 & 100 & 50 & 50 & 46 & 100 \\
\hline
\end{tabular}

Source: own elaboration on the basis of: [GRI Sustainability Disclosure Database...; Raport finansowy i spoteczny..., 2017; Raport Zrównoważonego Rozwoju,..., 2017; Sprawozdanie na temat informacji niefinansowych...., 2017].

The presented companies are characterized by diverse level of using GRI indicators referring to certain Sustainable Development Goals which may be observed while making comparison both between particular countries and inside those countries. Despite these differences the conducted analysis enables the indication of countries that are most characteristic in this aspect, i.e.: the Netherlands, Spain and Germany.

The comparison of Polish companies with the companies from other European countries is not favorable in this aspect. One may observe that only in the report prepared by Millennium Bank the level of using GRI indicators that coincide with particular Sustainable Development Goals may be compared with the results achieved by most entities from other countries. An entirely different situation regards other analyzed Polish companies. It results from the fact that JSW and Inter Cars are the only entities (apart from AMAG Metall from Austria) where the degree of using GRI indicators with regards to each among 17 Sustainable Development Goals was not higher than $50 \%$. It can be somehow justified by the fact that the reports for 2017 are the first documents of this type that were prepared by both companies.

On the basis of the prepared analysis one may observe that while it is difficult to point at the priority Sustainable Development Goals that would be mutual for the companies from all the analyzed countries, there is no problem with specifying the areas to which entities attach least importance. They concern mostly the same issues that are overlooked also by Polish companies (Partnerships for the goals, Sustainable cities and communities, Clean water and sanitation, as well as Reduced inequalities).

\section{Conclusions}

The realization of Sustainable Development Goals requires a number of actions to be taken by companies. However, in the times of the information society it is not satisfactory. What is crucial as well is the measurement and submitting of data connected with it. It enables the limitation of the information asymmetry on the market, whereas from the perspective of companies it creates the possibility to assess 
whether the undertaken activities constitute the reflection of major economic, environmental and social impacts.

Communication on the activities of companies in the sphere of sustainable development takes place mainly in the form of non-financial reporting. Since these reports are not regulated by regulations they differ from one another not only in terms of the scope, but also as regards the quality and transparency. Companies prepare reports using their own principles regarding reporting or they use the national, EU or international guidelines/standards. Therefore, large importance is attached to the creation of credible frameworks for reporting on the issues related to sustainable development that would be on a global scale and would guarantee the consistency of languages and indicators. In this aspect a particular role may be played by the latest GRI Standards - Standards of Reporting on Sustainable Development that constitute a reliable instrument for a large group of stakeholders. The new format of GRI Standards will enable the introduction of further changes resulting from dynamic development in the sphere of reporting on sustainable development by means of:

- updating individual standards from particular spheres where necessary,

- introducing clear distinction between requirements, recommendations and guidelines, which will enable easier implementation of Standards,

- improving the quality of the technical contents of Standards in order to eliminate ambiguity and contradictory interpretations for the reporting entities and for information recipients.

Undoubtedly, basing non-financial reports on GRI Standards will improve their reliability. They will be also more strategic and concentrated as well as easier to interpret for the interested groups of stakeholders.

\section{References}

Anam L., 2013, Zasady raportowania - podstawa prawidłowego sporzqdzania raportów, [w:] Wspólna odpowiedzialność. Rola raportowania spotecznego, Ćwik N. (red.), Forum Odpowiedzialnego Biznesu, Warszawa.

Business Strategy for Sustainable Development: Leadership and Accountability for the 90s, 1992, IISD, WBCSD Deloitte\&Touche, Winnipeg.

Gadomska-Lila K., Wasilewicz J., 2016, Zrównoważony rozwój i spoteczna odpowiedzialność zperspektywy biznesowej, „Studia i Prace WNEIZ US”, nr 46/1, DOI: 10.18276/ sip.2016.46/1-23.

Global Compact Poland, 2016, Global Compact Yearbook 2016/2017. Sustainable development goals for Poland, http://ungc.org.pl/wp-content/uploads/2016/11/GCYB _2016_all_small-1.pdf [date of entry: 11.04.2018].

Global Reporting Intitiative, 2011, Sustainability Reporting Guidelines. Version 3.1, https:/ / www.globalreporting.org/resourcelibrary/G3.1-Guidelines-Incl-Technical-Protocol.pdf [date of entry: 15.03.2018]. 
Global Reporting Intitiative, 2016, GRI Sustainability Reporting Standards 2016, https: //www.globalreporting.org/standards/gri-standards-download-center/ [date of entry: 08.04.2018].

Global Reporting Initiative, UN Global Compact, 2017, Business reporting on the SDGs. An analysis of the goals and targets, https://www.globalreporting.org/resourcelibrary/GRI_UNGC_Business-Reporting-on-SDGs_Analysis-of-Goals-andTargets.pdf, [date of entry: 02.05.2018].

GRI Sustainability Disclosure Database, http://database.globalreporting.org/search/ [date of entry: 04.05.2018].

Jastrzębska E., 2016, Bižnes na rzecz rožpoju zrównowa żonego - dobre praktyki, „Ekonomia XXI wieku", nr 4(12), DOI: 10.15611/e21.2016.4.03.

Kaputa J., 2013, Raportowanie zrównoważonego rozwoju jako wyzwanie dla przedsiebiorstw XXI wieku, „Zarządzanie i Finanse”, nr 1, cz. 2.

Michalczuk G., Konarzewska U., Mikulska T., 2017, Raport zintegrowany jako praykktad nowego podejścia do sprawozdawczości biznesowej przeedsiebiorstw, „Przedsiębiorstwo \& Finanse", nr 3(18).

Raport finansony $i$ społeczny Banku Millenium, 2017, https://raportroczny.bankmillennium.pl/2017/pl/ [date of entry: 02.05.2018].

Raport zrónnoważonego roz̧oju Grupy JSW, 2017, https://www.jsw.pl/fileadmin/user_ files/odpowiedzialny-biznes/raport-csr-2017/jsw-raport-csr.pdf [data wejścia: 02.05.2018].

Rogall H., 2010, Ekonomia zrównoważonego rozwoju. Teoria i praktyka, Wydawnictwo Zysk i S-ka, Poznań.

SDG Compass. Linking the SDGs and GRI, https://www.globalreporting.org/resourcelibrary/SDG_GRI_LInkage.pdf [date of entry: 03.04.2018].

SDG Compass. The guide for business action on the SDGs, https://www.globalreporting. org/resourcelibrary/GSSB-Item-29-SDGCompass-Meeting5Nov15.pdf [date of entry: 03.04.2018].

Sikacz H., 2017, Ocena raportów zintegrowanych grup kapitałowych na podstawie wskaźnikón szczegótonych, „Prace Naukowe Uniwersytetu Ekonomicznego we Wrocławiu”, nr 479, DOI: 10.15611/pn.2017.479.13.

Sprawozdanie na temat informacii niefinansonych InterCars S. A. i Grupy Kapitatowej InterCars S.A., 2017, http://inwestor.intercars.com.pl/files//raporty/niefinansowe/ICraport-niefinansowy-2017.pdf [date of entry: 02.05.2018].

Śnieżek E., Wiatr M., 2014, Zintegrowane raportowanie biznesowe pržedsiębiorstwa spotecznie odpowiedrialnego w dobie zrównoważonego rozwoju, „Studia Prawno-Ekonomiczne”, t. XCI $/ 2$.

Wróbel M., 2016, Raportowanie spotecznej odpowiedzialności w Polsce w swietle unormowań Dyrektywy Parlamentu Europejskiego i Rady 2014/95/UE, „Zeszyty Naukowe Wyższej Szkoły Humanitas. Zarządzanie”, nr 2, DOI: 10.5604/18998658.1209978. 